\title{
Covariation between plant biodiversity and soil systems in a European beech forest and a black pine plantation: the case of Mount Faito, (Campania, Southern Italy)
}

\author{
Tiziana Danise ${ }^{1} \cdot$ Michele Innangi $^{1} \cdot$ Elena Curcio $^{1} \cdot$ \\ Antonietta Fioretto ${ }^{1}$
}

Received: 2 February 2021 / Accepted: 15 March 2021 / Published online: 3 May 2021

(C) The Author(s) 2021

\begin{abstract}
Both climate and land-use changes, including the introduction and spread of allochthonous species, are forecast to affect forest ecosystems. Accordingly, forests will be affected in terms of species composition as well as their soil chemical and biological characteristics. The possible changes in both tree cover and soil system might impact the amount of carbon that is stored in living plants and dead biomass and within the soil itself. Additionally, such alterations can have a strong impact on the detrital food web that is linked to litter decomposition. Although there are studies on the influence of plant diversity on soil physical and chemical characteristics, the effects on soil biological activity and carbon storage processes remain largely unknown. The aim of this study was to investigate and compare chemical and biological variables in covariation with plant communities in an autochthonous beech forest (Fagus sylvatica L.) and a black pine plantation (Pinus nigra J.F. Arnold subsp. nigra). Our results confirmed that the two communities were considerably different, with the old-growth beech community having a lower number of plant species and the pine community was in development as a consequence of anthropogenic activities. These aspects of the two communities were also reflected in the soil, with the beech soil having higher
\end{abstract}

Project funding: This work did not receive any fundings.

The online version is available at http://www.springerlink.com.

Corresponding editor: Yu Lei.

Michele Innangi

michele.innangi@unicampania.it

1 Department of Environmental, Biological and Pharmaceutical Sciences and Technologies, University of Campania "Luigi Vanvitelli", Via Vivaldi 43, 81100 Caserta, Italy nitrogen levels and a more specialized microbial community compared to the pine soil, with most extracellular enzymes (such as peroxidase and chitinase) showing lower activity in the pine soil.

Keywords 2B-PLS · Plant and soil · Vegetation $\cdot$ Soil enzymes

\section{Introduction}

The relationship between biodiversity and ecosystem functioning is an important topic, especially with a global change perspective (Midgley and Thuiller 2005; Flynn et al. 2011). Understanding whether and to what extent future environmental conditions will affect the relationships between biodiversity and ecosystem functions becomes an important consideration. This is particularly true for forest ecosystems, which are predicted to be strongly affected by climate change (Milad et al. 2011; Noce et al. 2017), as well as plant or animal allochthonous species, ones that are able to reproduce and colonize a new environment with potential harmful consequences on autochthonous communities (Sitzia et al. 2016; Campagnaro et al. 2018). For forests, their soils are of significant interest, especially considering the large number of ecosystem processes they provide, including carbon storage and litter decomposition (Lal 2005; Pan et al. 2011; McDaniel et al. 2013). However, studies that look at the interrelationships between plant biodiversity under different covers and soil functions are comparatively scarce, especially when considering biological activities (such as extracellular enzyme activities) by the microbial community (Vittori Antisari et al. 2011; Innangi et al. 2015a, b, 2019; Curcio et al. 2017; Panico et al. 2018). Evidence suggests a positive effect of plant species diversity on ecosystem 
primary productivity by means of a more efficient use of resources (Loreau et al. 2001). In this case, a rise in plant productivity and diversity could lead to a greater carbon accumulation in above-ground and below-ground plant biomass (Masera et al. 2003; Jandl et al. 2007; Schulp et al. 2008). Consequently, an increase in primary productivity will contribute more plant litter to the soil where organisms, especially fungi and bacteria, play fundamental roles in the decomposition and mineralization of organic matter (Sanderman and Amundson 2003), along with a crucial contribution of saproxylic insects (Parisi et al. 2018). Since wood is a carbon sink and also due to its resistance to degradation, the importance of forests as carbon sinks in live plants and dead biomass is unquestionable (Schimel et al. 2001). Given the increased litter input to soil, it is also essential to understand how diversity in plant species influences the soil system and the activity of the organisms that populate it, as diverse systems lead to miscellaneous litter inputs and-as a consequence-dissimilar microbial communities, especially when considering the alteration that might derive from the introduction of alien species ( Sladonja et al. 2015; Vilà et al. 2011). This study investigates the relationship between plant biodiversity and the functional diversity of soil microbial communities expressed as extracellular enzyme activities within small-scale ecosystems, one with autochthonous vegetation and the other with a century-old plantation. Accordingly, the study was conducted in two forest sites that differed in dominant tree cover, (i.e., a plantation of Pinus nigra J. F. Arnold subsp. nigra and an old-growth Fagus sylvatica $\mathrm{L}$. forest). Both were established at elevations less than $150 \mathrm{~m}$ apart and on similar parental material within the area of Mount Faito in the Italian Southern Apennines. These stands were chosen as the pine is not autochthonous in this area of Italy and was planted, while the beech forest is typical climax vegetation of the area. Our goal was to shed new light on patterns of covariation between understory biodiversity and soil functions, a critical step in understanding how these interactions might alter under climate change scenarios, as well as the impact of land-use changes and anthropogenic activities by means of allochthonous species.

\section{Materials and methods}

\section{Site description}

The research sites are both located on Mount Faito within the Monti Lattari Regional Park (Campania, Southern Italy). Here the limestone bedrock is covered by quaternary deposits and, especially on the northern slopes, by volcanic deposits from the Vesuvian and Phlegraean areas (Curcio et al. 2017), creating different types of Andisols (Di Gennaro et al. 2002). The temperate climate is relatively humid throughout the year with heavy rainfalls in the DecemberFebruary cold season, with occasional snowfalls. Rainfall also occurs during summer months, resulting in rare water stress periods even in full summer. Total annual rainfall is approximately $960 \mathrm{~mm}$ and average annual temperature $13.7^{\circ} \mathrm{C}$. Temperatures show a marked seasonality: average temperature of the coldest month is $6.5^{\circ} \mathrm{C}$ whereas that of the warmest is $23^{\circ} \mathrm{C}$.

In this study, two sites were identified in spring 2018, one with a Fagus sylvatica cover $\left(40.658354^{\circ} \mathrm{N}, 14.495115^{\circ}\right.$ E, $1238 \mathrm{~m}$ a.s.1.), and the other with a Pinus nigra subsp. nigra cover $\left(40.664167^{\circ} \mathrm{N}, 14.479722^{\circ} \mathrm{E}, 1104 \mathrm{~m}\right.$ a.s.1.). The beech stand is an old-growth forest without recent management history, hosting some trees older than 400 years, although most are different age and size (Stinca et al. 2020). The pine plantation was established on Mount Faito during the nineteenth century, and the oldest trees are over 100 years (Cavara 1914). Soil profiles for nearby plots were described in October 2013 and were Vitric Leptic Andisol and Mollic Eutrisilic Andisol for the beech stand and pine plantation, respectively. The beech stand had a loam sandy texture, while soil under the pine plantation ranged from sandy loam to loamy sand (Curcio et al. 2017).

\section{Soil sampling and sample preparation}

Soil samples were taken in the spring of 2018 at the beginning of the growing season in three plots within each stand. Plots in each stand were chosen at the same elevation and aspect, with 20-m between each. In order to interpret soil spatial heterogeneity, at the center of each plot and $50 \mathrm{~cm}$ on the left and the right, soil samples were taken with a steel corer $40 \mathrm{~cm}$ long $\times 5 \mathrm{~cm}$ diameter after removing the organic layer (De Marco et al. 2016; Fioretto et al. 2018). Samples were kept in refrigerated containers until processing in the laboratory. Each core was separated into sub-samples corresponding to depths of $0-5,5-10,10-15,15-20,20-25$, and $25-40 \mathrm{~cm}$ (Curcio et al. 2017). Following separation, field replicates were pooled. Samples were sieved ( $2 \mathrm{~mm}$ mesh) to remove gravel and roots, and an aliquot was dried at $75^{\circ} \mathrm{C}$ for $48 \mathrm{~h}$ to determine water content. The same material was then used to determine nitrogen $(\mathrm{N})$ and organic matter contents. A second aliquot was temporarily stored at $4{ }^{\circ} \mathrm{C}$ for active fungal biomass determination (Papa et al. 2014). The remaining portion was stored at $-80{ }^{\circ} \mathrm{C}$ for enzyme activity measurements (Fioretto et al. 2018).

\section{Chemical analyses}

Organic matter was the difference between the dry weight and the ashes after ignition at $375^{\circ} \mathrm{C}$ for $16 \mathrm{~h}$ of dried, finely ground samples (Innangi et al. 2015a). Organic carbon (C) was calculated by dividing the amount of organic matter 
by a factor of 2 (Pribyl 2010; Innangi et al. 2017b). pH was measured after shaking soil samples in water (1:2.5) for $30 \mathrm{~min}$ and subsequent centrifugation at $2000 \mathrm{~g}$ for $10 \mathrm{~min}$ (De Marco et al. 2016). Total N content was determined by CHNS analyzer (Danise et al. 2018) and was used to compute C:N ratios. All measurements were replicated twice.

\section{Biological activities}

Active fungal biomass was evaluated by a direct method that involves counting the intersections of fungal hyphae on a screen mounted into a microscope eyepiece (Olson 1950). The suspension of fungal hyphae and their coloring was performed according to Söderström (1977), while the method of Sundman and Sivelä (1978) was followed for the conversion of the number of intersections into biomass (Marzaioli et al. 2010; Panico et al. 2020). For extracellular enzyme activities, the following general procedure was used that varied according to each enzyme. An aliquot of soil ( 0.2 to $1.0 \mathrm{~g}$, according to organic matter content) was put in centrifuge tube and a buffer solution (according to the optimum of the enzyme being tested) and a substrate were added. The samples were incubated in a water bath at the optimum temperature for each enzyme and for 1 to $3 \mathrm{~h}$. Following incubation, different reagents were added according to the enzyme which developed a color that could be read in a UV-VIS spectrophotometer against a calibration curve. For additional details, cellulase and xylanase activities were evaluated according to Schinner and Von Mersi (1990), chitinase and dehydrogenase according to Verchot and Borelli (2005) and Von Mersi and Schinner (1991), with a few modifications. Laccase and peroxidase activities were determined according to Leatham and Stahamann (1981) with modifications (Di Nardo et al. 2004). All measurements were replicated twice.

\section{Vegetation survey}

In each of the three plots within the stands, vegetation was surveyed according to Braun-Blanquet (1964). Relevés or small plots were centered on the soil sampling plots and vegetation was qualitatively and quantitatively evaluated on an $8 \times 8 \mathrm{~m}$ area between March and June 2018. The aim of the vegetation survey was not to describe the plant community in detail but to investigate possible linkages between aboveground and belowground ecological connections under the two forest covers. Accordingly, the survey was limited to 64 $\mathrm{m}^{2}$ of stand in order to identify the main plant communities affecting the underlying soil, while keeping enough space between each plot that were $20 \mathrm{~m}$ apart. Plant nomenclature followed Bartolucci et al. (2018). In both beech and pine stands, the mean abundance of each taxon, i.e. for taxon $i$ in the plot $j$, abundance was reported as:

mean abundance $=\frac{n_{i, j}}{\sum_{i} n_{i, j}} \times 100$

The amount of cover of each taxon was estimated according to the Braun-Blanquet method, i.e., attributing a value of 1 for taxa $\leq 5 \%$ of the surface (although with several specimens), and ' 5 for taxa that covered $75-100 \%$ of the plot. Taxa which had $\leq 5 \%$ of the surface cover and had few individuals were recorded as + or ++ , to indicate their rarity (Braun-Blanquet 1964).

\section{Diversity indexes}

In each plot were recorded the number of taxa $(S)$ and the number of individuals $(n)$, dominance $(D)$ was reported as ranging from 0 (equal abundance of each taxon) to 1 (a single species dominating the others) and computed as:

$D=\sum_{i}\left(\frac{n_{i}}{n}\right)^{2}$

Shannon diversity index $(H)$, as a measure of entropy of the community, was measured as:

$H=-\sum_{i}\left(\frac{n_{i}}{n}\right) \ln \left(\frac{n_{i}}{n}\right)$

Buzas-Gibson's Evenness $(E)$ was measured as:

$E=e^{H} / S$

Equitability (Pielou's evenness) $(J)$ was measured as:

$J=H / \ln S$

Fisher's diversity index (A), considering $\alpha$ as Fisher's alpha, was measured as:

$A=n^{1-\alpha / \alpha}$ with $\frac{S}{n}=\frac{1-\alpha}{\alpha(-\ln (1-\alpha))}$

\section{Ellenberg's indicator values}

For each taxon, Ellenberg's indicator values were extracted for the Italian flora (Pignatti et al. 2005; Guarino et al. 2012) using package 'TR8' (Bocci 2015). The indicator values are $\mathrm{L}, \mathrm{T}, \mathrm{K}, \mathrm{U}, \mathrm{pH}$, and $\mathrm{N}$, light, temperature, continentality, soil moisture, soil reaction, and soil nutrient content indicators, respectively. No value for salinity (S) was reported as all species had a value of 0 . Additional information is available in Pennesi (2017). For species that had a broad range of 
indicator value ( $\mathrm{X}$ in the original data), the maximum value was used plus 1 for computational reasons. For the indicator value for the plot, the weighted mean of the $i^{\text {th }}$ species indicator value multiplied by the number of individuals of that species was computed. For instance, the plot level indicator for T would be:

$T_{\text {plot }}=\sum_{i} \frac{T_{i} \times n_{i}}{n}$

\section{Statistics}

All values are mean \pm standard error of the mean. For soil chemical and biological variables, the effects of factor cover and layer with their interaction was evaluated by a multivariate approach using two-way permutational multivariate analysis of variance (PERMANOVA) using 999 permutations and Euclidean distance matrices. All variables were scaled and centered before the analyses. Patterns of covariance between soil chemical/biological variables and vegetation diversity and Ellenberg's indicator values were tested using two-block partial least squares (2B-PLS). Partial least square regression analyze related predictor variables with a sample size not as large as the number of independent variables (Carrascal et al. 2009). Given two matrixes with different variables but the same observations, 2B-PLS builds pairs of variables as linear combinations within each of the two sets in order to explain as much covariance as from the original sets (Rohlf and Corti 2000). This statistical approach has been used successfully on several ecological studies (Innangi et al. 2017a, 2018, 2019, 2020; Battipaglia et al. 2020). Statistical analyses were performed using software R version 3.6.0 (R Core Team 2019) and packages 'vegan' (Oksanen et al. 2013), 'ggplot2' (Wickham 2016) and 'plsdepot' (Sanchez 2012).

\section{Results}

\section{Soil chemical variables}

According to the two-way PERMANOVA results, the two stands were significantly different for both canopy cover and

Table 1 Two-way PERMANOVA for soil chemical variables

\begin{tabular}{lrllll}
\hline Factor & Df & Sum of sqs & $R^{2}$ & \multicolumn{1}{l}{ F } & $p(>\mathrm{F})$ \\
\hline Cover & 1 & 33.57 & 0.24 & 94.77 & 0.001 \\
Soil depth & 5 & 80.79 & 0.58 & 45.62 & 0.001 \\
C $\times$ SD & 5 & 17.13 & 0.12 & 9.67 & 0.001 \\
Residual & 24 & 8.50 & 0.06 & & \\
Total & 35 & 140 & 1.00 & & \\
\hline
\end{tabular}

soil depth (Table 1), with significant changes according to their interaction. The differences were largely due to factor soil depth $\left(R^{2}=0.58, p<0.001\right)$, given that in both stands, a general decreasing trend with depth could be observed. Such a trend implied a decrease in carbon and nitrogen in both stands, while only $\mathrm{pH}$ increased with depth (Table 2). For $\mathrm{C}: \mathrm{N}$ ratios, there was no general trend between stands and soil depth (Table 2). Allow less important than variation according to depth, findings under different vegetative cover were significant $\left(R^{2}=0.24, p<0.001\right)$. The mean $\mathrm{pH}$ was higher under pine compared to beech $(6.2 \pm 0.0$ vs. $5.6 \pm 0.1$, respectively), while both stands showed similar $C$ values (Table 2). In contrast, the soil under beech had larger nitrogen levels compared to the pine soil $(0.6 \pm 0.1$ vs. $0.5 \pm 0.1$, respectively) which resulted in differences in the $\mathrm{C}: \mathrm{N}$ ratios $(16.4 \pm 0.7$ vs. $22.5 \pm 1.3$, respectively).

\section{Soil biological variables}

Two-way PERMANOVA results showed that both covers and soil depth had a significant effect on soil biological variables, but there was no significant interaction of the two

Table 2 Mean \pm standard errors for soil chemical variables by stand cover and soil depth

\begin{tabular}{lllrll}
\hline Cover & Soil depth & pH & \multicolumn{1}{l}{$\begin{array}{l}\text { Carbon } \\
(\%)\end{array}$} & $\begin{array}{l}\text { Nitrogen } \\
(\%)\end{array}$ & C:N \\
\hline Beech & $0-5 \mathrm{~cm}$ & $5.1 \pm 0.1$ & $21.0 \pm 1.2$ & $1.3 \pm 0.0$ & $16.40 \pm 0.60$ \\
& $5-10 \mathrm{~cm}$ & $5.3 \pm 0.1$ & $13.8 \pm 1.5$ & $0.8 \pm 0.1$ & $16.9 \pm 1.0$ \\
& $10-15 \mathrm{~cm}$ & $5.6 \pm 0.1$ & $10.3 \pm 0.9$ & $0.7 \pm 0.1$ & $15.7 \pm 1.7$ \\
& $15-20 \mathrm{~cm}$ & $5.8 \pm 0.1$ & $5.5 \pm 0.5$ & $0.3 \pm 0.0$ & $20.21 \pm 0.29$ \\
& $20-25 \mathrm{~cm}$ & $5.9 \pm 0.1$ & $5.0 \pm 0.4$ & $0.3 \pm 0.0$ & $16.8 \pm 1.8$ \\
& $25-40 \mathrm{~cm}$ & $6.0 \pm 0.1$ & $4.4 \pm 0.8$ & $0.4 \pm 0.1$ & $12.6 \pm 2.0$ \\
& Mean & $5.6 \pm 0.1$ & $10.0 \pm 1.5$ & $0.6 \pm 0.1$ & $16.4 \pm 0.7$ \\
Pine & $0-5 \mathrm{~cm}$ & $6.00 \pm 0.1$ & $22.8 \pm 0.9$ & $1.0 \pm 0.1$ & $23.1 \pm 0.4$ \\
& $5-10 \mathrm{~cm}$ & $6.1 \pm 0.1$ & $12.9 \pm 0.1$ & $0.7 \pm 0.1$ & $19.1 \pm 1.1$ \\
& $10-15 \mathrm{~cm}$ & $6.2 \pm 0.1$ & $8.6 \pm 0.8$ & $0.5 \pm 0.0$ & $18.3 \pm 1.9$ \\
& $15-20 \mathrm{~cm}$ & $6.3 \pm 0.1$ & $6.6 \pm 0.2$ & $0.4 \pm 0.0$ & $18.9 \pm 0.9$ \\
& $20-25 \mathrm{~cm}$ & $6.3 \pm 0.1$ & $5.4 \pm 0.4$ & $0.2 \pm 0.0$ & $22.8 \pm 2.3$ \\
& $25-40 \mathrm{~cm}$ & $6.4 \pm 0.1$ & $3.9 \pm 0.4$ & $0.1 \pm 0.0$ & $32.8 \pm 2.7$ \\
& Mean & $6.2 \pm 0.0$ & $10.0 \pm 1.6$ & $0.5 \pm 0.1$ & $22.5 \pm 1.4$ \\
\hline
\end{tabular}

Table 3 Two-way PERMANOVA for soil biological variables

\begin{tabular}{lrllll}
\hline Factor & Df & Sum of Sqs & $R^{2}$ & F & $p(>\mathrm{F})$ \\
\hline Cover & 1 & 24.30 & 0.10 & 8.47 & 0.001 \\
Soil depth & 5 & 133.04 & 0.54 & 9.27 & 0.001 \\
C $\times$ SD & 5 & 18.78 & 0.08 & 1.31 & 0.229 \\
Residual & 24 & 68.88 & 0.28 & & \\
Total & 35 & 245 & 1.00 & & \\
\hline
\end{tabular}


(Table 3). The majority of variation was explained by soil depth $\left(R^{2}=0.54, p<0.001\right)$, with a tendency to decrease all biological activities with depth (Table 4). Such decreasing trend with depth was sharper for some biological activities (e.g., AFB, dehydrogenase, and laccase) compared to others (e.g., xylanase and peroxidase) (Table 4). Despite the low yet significant variation as a result of cover $\left(R^{2}=0.10\right.$, $p<0.001)$, the soil under beech had consistently higher chitinase, dehydrogenase, and peroxidase activity, while under pine only cellulase activity was higher (Table 4). The remaining biological activities tested (i.e., AFB, xylanase, and laccase) were comparable between the two stands.

\section{Vegetation survey}

The beech plots were dominated by European beech (Fagus sylvatica) but not numerically ( $2.4 \%$, Table 5$)$. The canopy also included Italian alder (Alnus cordata (Loisel.) Duby, abundance $0.3 \%$ ) and Italian maple (Acer opalus Mill. subsp. obtusatum (Waldst. \& Kit. ex Willd.) Gams, abundance $0.1 \%$ ). The beech understory included abundant blue anemones (Anemone apennina L.), two-leafed squill, (Scilla bifolia L.), ivy-leaved cyclamen (Cyclamen hederifolium Aiton subsp. hederifolium), and early dog-violet (Viola reichenbachiana Jord. ex Boreau) with a few other species (Table 5). The pine plots were dominated by Austrian pine (Pinus nigra subsp. nigra, abundance $0.3 \%$ ), but also included other species such as sweet chestnut (Castanea sativa Mill.), European beech (Fagus sylvatica), Italian maple and some small European silver fir (Abies alba Mill.). The understory had a large number of taxa, dominated by blue anemones, blackberry (Rubus hirtus Waldst. \& Kit. group), and lesser periwinkle (Vinca minor L.).

\section{Vegetation diversity and Ellenberg's indicator values}

The pine plantation had a remarkably larger number of species and individuals with an average of 19 taxa compared to the beech stand, with an average of 7 (Table 6). Such greater richness was reflected in higher Shannon and Fisher's alpha diversity indexes for the pine compared to the beech stands (Table 6). In contrast, the beech plots had a greater dominance index as well as a greater community evenness, while equitability was comparable between the two stands (Table 6). Ellenberg's indicator values at the plot level are in Table 7. The beech plots had a noticeably higher $\mathrm{U}$ value (soil moisture), but also indicator values for temperature, continentality and $\mathrm{pH}$ were higher. In contrast, the pine stands had marginally higher light values whereas nutrient content was comparable between stands (Table 7).

\section{Two-block partial least squares analyses}

The results of the 2B-PLS analysis between soil chemical and biological variables (block 1) and vegetation diversity indexes (block 2) are shown in Fig. 1. The amount of explained variance was 52\% and 56\% for block 1 and block 2 , respectively. The scatterplot showed a sharp separation of pine plots in the upper right quadrant (black triangles) from the beech plots in the lower left (white circles). From the correlation plots within and between the two blocks, it can be seen that pine plots were separated by $\mathrm{pH}, \mathrm{C}: \mathrm{N}$ ratios,

Table 4 Means \pm standard errors for soil biological variables by stand cover and soil depth

\begin{tabular}{lllllllll}
\hline Cover & Soil depth & AFB & Cellulase & Xylanase & Chitinase & DHA & Laccase & Peroxidase \\
\hline Beech & $0-5 \mathrm{~cm}$ & $1.04 \pm 0.09$ & $0.23 \pm 0.02$ & $0.24 \pm 0.01$ & $0.54 \pm 0.12$ & $2.28 \pm 0.29$ & $0.25 \pm 0.09$ & $2.40 \pm 1.00$ \\
& $5-10 \mathrm{~cm}$ & $0.80 \pm 0.05$ & $0.18 \pm 0.02$ & $0.19 \pm 0.01$ & $0.44 \pm 0.1$ & $1.13 \pm 0.15$ & $0.07 \pm 0.02$ & $3.05 \pm 0.87$ \\
& $10-15 \mathrm{~cm}$ & $0.80 \pm 0.14$ & $0.10 \pm 0.02$ & $0.17 \pm 0.01$ & $0.28 \pm 0.05$ & $0.53 \pm 0.06$ & $0.03 \pm 0.00$ & $1.58 \pm 0.30$ \\
& $15-20 \mathrm{~cm}$ & $0.86 \pm 0.16$ & $0.05 \pm 0.01$ & $0.17 \pm 0.01$ & $0.25 \pm 0.05$ & $0.41 \pm 0.07$ & $0.06 \pm 0.03$ & $1.50 \pm 0.23$ \\
& $20-25 \mathrm{~cm}$ & $0.94 \pm 0.16$ & $0.05 \pm 0.00$ & $0.17 \pm 0.02$ & $0.17 \pm 0.04$ & $0.49 \pm 0.08$ & $0.04 \pm 0.01$ & $0.99 \pm 0.43$ \\
& $25-40 \mathrm{~cm}$ & $0.94 \pm 0.10$ & $0.03 \pm 0.00$ & $0.16 \pm 0.01$ & $0.14 \pm 0.01$ & $0.42 \pm 0.06$ & $0.03 \pm 0.01$ & $0.49 \pm 0.04$ \\
& Mean & $0.90 \pm 0.05$ & $0.11 \pm 0.02$ & $0.18 \pm 0.01$ & $0.30 \pm 0.04$ & $0.88 \pm 0.17$ & $0.08 \pm 0.02$ & $1.67 \pm 0.29$ \\
Pine & $0-5 \mathrm{~cm}$ & $1.18 \pm 0.16$ & $0.26 \pm 0.01$ & $0.23 \pm 0.01$ & $0.56 \pm 0.14$ & $1.23 \pm 0.13$ & $0.16 \pm 0.01$ & $0.50 \pm 0.22$ \\
& $5-10 \mathrm{~cm}$ & $0.87 \pm 0.02$ & $0.24 \pm 0.001$ & $0.21 \pm 0.01$ & $0.26 \pm 0.06$ & $0.74 \pm 0.06$ & $0.10 \pm 0.01$ & $1.50 \pm 0.93$ \\
& $10-15 \mathrm{~cm}$ & $0.88 \pm 0.10$ & $0.20 \pm 0.01$ & $0.17 \pm 0.02$ & $0.11 \pm 0.02$ & $0.57 \pm 0.03$ & $0.07 \pm 0.02$ & $1.18 \pm 0.57$ \\
& $15-20 \mathrm{~cm}$ & $0.72 \pm 0.08$ & $0.18 \pm 0.01$ & $0.17 \pm 0.03$ & $0.09 \pm 0.01$ & $0.37 \pm 0.11$ & $0.15 \pm 0.10$ & $0.78 \pm 0.16$ \\
& $20-25 \mathrm{~cm}$ & $0.71 \pm 0.16$ & $0.16 \pm 0.01$ & $0.16 \pm 0.04$ & $0.08 \pm 0.02$ & $0.30 \pm 0.13$ & $0.04 \pm 0.02$ & $0.35 \pm 0.06$ \\
& $25-40 \mathrm{~cm}$ & $0.62 \pm 0.09$ & $0.14 \pm 0.01$ & $0.15 \pm 0.03$ & $0.03 \pm 0.01$ & $0.24 \pm 0.06$ & $0.02 \pm 0.01$ & $0.16 \pm 0.01$ \\
& Mean & $0.83 \pm 0.06$ & $0.20 \pm 0.01$ & $0.18 \pm 0.01$ & $0.19 \pm 0.05$ & $0.58 \pm 0.09$ & $0.09 \pm 0.02$ & $0.74 \pm 0.19$ \\
\hline
\end{tabular}

Active fungal biomass (AFB) is mg dry fungal biomass $\mathrm{g}^{-1}$ dry weight, cellulase and xylanase are $\mu$ mol glucose equivalent $\mathrm{g}^{-1}$ dry weight $\mathrm{h}^{-1}$, chitinase is $\mu \mathrm{mol}$ para-nitrophenol $\mathrm{g}^{-1}$ dry weight $\mathrm{h}^{-1}$, dehydrogenase (DHA) is $\mu$ mol iodonitrotetrazolium violet-formazan $\mathrm{g}^{-1}$ dry weight $\mathrm{h}^{-1}$, laccase and peroxidase are $\mu \mathrm{mol}$ oxidized ortho-toluidine $\mathrm{g}^{-1}$ dry weight $\mathrm{h}^{-1}$ 


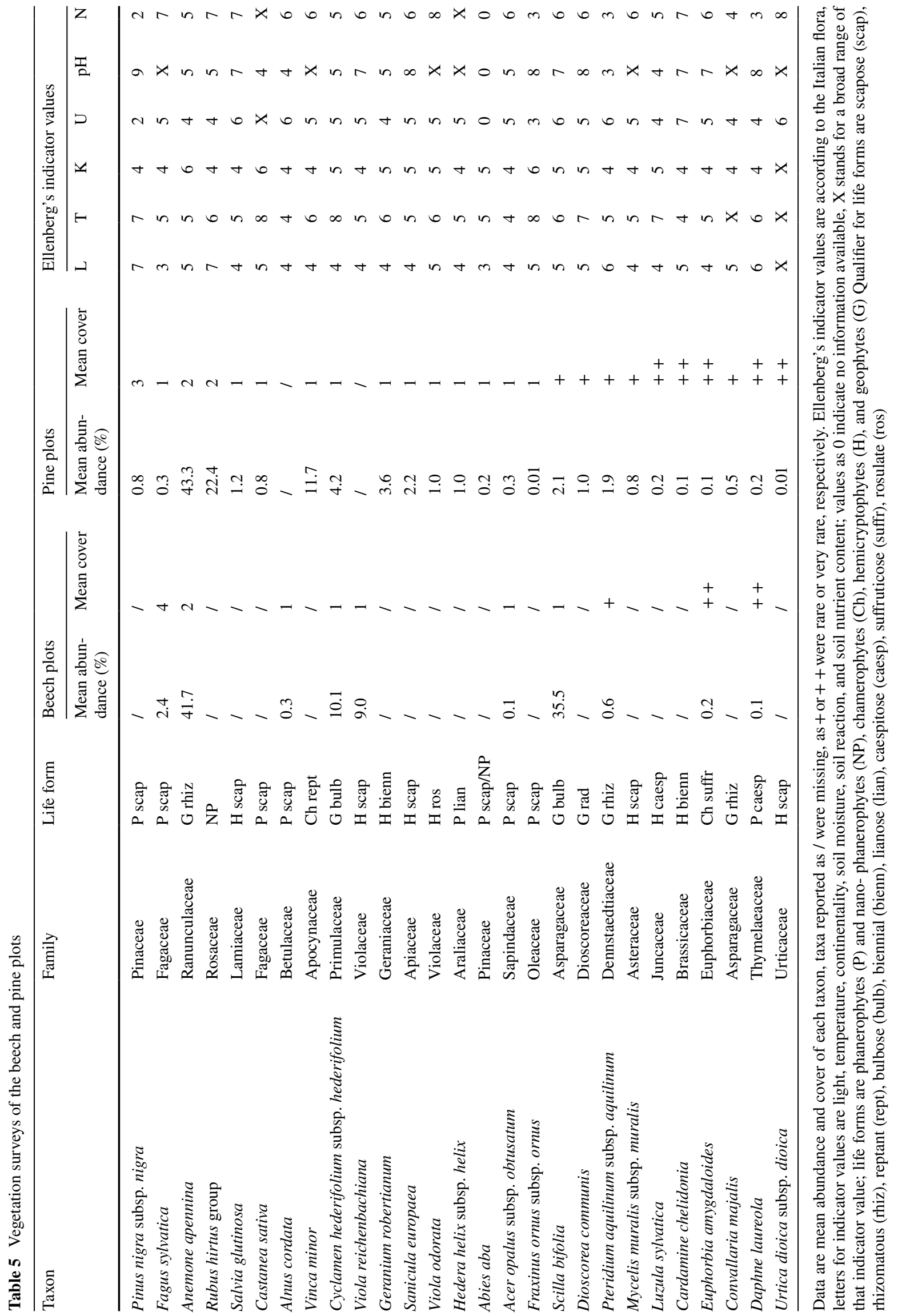


Table 6 Summary of diversity indexes for beech and pine plots

\begin{tabular}{|c|c|c|c|c|c|c|c|c|}
\hline Cover & Plot & Richness (S) & Individuals (n) & Dominance (D) & Shannon $(\mathrm{H})$ & Evenness (E) & Equitability (J) & $\begin{array}{l}\text { Fisher's } \\
\text { Alpha (A) }\end{array}$ \\
\hline \multirow[t]{4}{*}{ Beech } & 1 & 5 & 295 & 0.36 & 1.14 & 0.63 & 0.71 & 0.86 \\
\hline & 2 & 9 & 543 & 0.28 & 1.41 & 0.45 & 0.64 & 1.53 \\
\hline & 3 & 7 & 271 & 0.44 & 1.02 & 0.40 & 0.52 & 1.31 \\
\hline & Mean & 7 & 370 & 0.36 & 1.19 & 0.49 & 0.62 & 1.23 \\
\hline \multirow[t]{4}{*}{ Pine } & 1 & 20 & 1601 & 0.35 & 1.55 & 0.23 & 0.52 & 3.22 \\
\hline & 2 & 17 & 596 & 0.23 & 1.89 & 0.39 & 0.67 & 3.26 \\
\hline & 3 & 19 & 294 & 0.24 & 1.83 & 0.33 & 0.62 & 4.54 \\
\hline & Mean & 19 & 830 & 0.28 & 1.76 & 0.32 & 0.60 & 3.67 \\
\hline
\end{tabular}

Table 7 Summary of Ellenberg's indicator values for beech and pine plots reported according to Italian flora; letters stand for light, temperature, continentality, soil moisture, soil reaction, and soil nutrient content

\begin{tabular}{llllllll}
\hline Cover & Plot & $\mathrm{L}$ & $\mathrm{T}$ & $\mathrm{K}$ & $\mathrm{U}$ & $\mathrm{pH}$ & $\mathrm{N}$ \\
\hline Beech & 1 & 4.8 & 6.0 & 5.3 & 5.2 & 6.1 & 5.5 \\
& 2 & 4.6 & 5.5 & 5.1 & 4.9 & 6.0 & 5.5 \\
& 3 & 4.9 & 5.4 & 5.5 & 4.8 & 5.9 & 5.4 \\
& Mean & 4.8 & 5.7 & 5.3 & 4.9 & 6.0 & 5.5 \\
& 1 & 5.0 & 5.2 & 5.0 & 4.1 & 5.5 & 5.2 \\
& 2 & 4.7 & 5.2 & 4.7 & 4.1 & 5.4 & 5.2 \\
& 3 & 5.5 & 5.8 & 4.8 & 4.4 & 6.2 & 6.1 \\
& Mean & 5.1 & 5.4 & 4.8 & 4.2 & 5.7 & 5.5 \\
\hline
\end{tabular}

and cellulase activity that corresponded to greater vegetation diversity in terms or richness (S) and both Fisher's alpha (A) and Shannon indexes $(\mathrm{H})$. In contrast, beech plots showed a consistent higher biological activity with dehydrogenase (DHA), peroxidase, and active fungal biomass (AFB), along with higher nitrogen contents. These soil variables reflect a plant community with a greater evenness (E) and dominance (D). Figure 2 shows the 2B-PLS analysis between the same soil variables (block 1) with Ellenberg's indicator values (block 2). The degree of explained variance was $53 \%$ and $40 \%$ for blocks 1 and 2, respectively. Again, the same separation of pine and beech plots can be seen. Pine plots were neatly separated according to their $\mathrm{pH}, \mathrm{C}: \mathrm{N}$ ratio, and cellulase activity, which is a reflection of a plant community with a greater light. The beech plots are separated mostly by their soil nitrogen content, along with DHA, peroxidase, and chitinase, corresponding to a community with species requiring higher soil humidity (U) and adapted to a greater continentality $(\mathrm{K})$.

\section{Discussion}

Although the bedrock in both locations is limestone, Mount Faito was impacted by the volcanic eruption of the Vesuvius-Monte Somma, thus a pyroclastic material is parent material in both sites. However, from a pedological view, the two soil profiles are quite different (Curcio et al. 2017). On the beech site, which has been most affected by pyroclastic depositions of the Vesuvius-Monte Somma complex (Carpaneto et al. 2006), a considerably thick layer of pumice between 25 and $80 \mathrm{~cm}$ in depth was deposited. The type of vegetation greatly influenced the physicochemical and biological characteristics of the soils. In general, soils developed under conifers have a more acidic $\mathrm{pH}$ than under broad-leaved species (Vittori Antisari et al. 2011). In this study, an opposite trend was identified that could be explained by the large amounts of humic and fulvic acid deposits recorded in Apennine beech forests (Danise et al. 2018), a consequence of decomposition of beech litter that has high concentrations of cellulose and lignin and comparatively high levels of $\mathrm{N}$ (Innangi et al. 2015b, 2018). Litter that is high in both lignin and $\mathrm{N}$ has a slow decay rate and can lead to the development of thick humified layers in the soil (Berg et al. 1995; Hedde et al. 2008; Danise et al. 2020).

Our results show that chemical variables decrease with depth. Regardless of plant cover, decreases in $\mathrm{C}$ and $\mathrm{N}$ contents with increasing depth were recorded. In line with our results, in more than 10,000 soil profiles, Jobbágy and Jackson (2000) found a higher concentration of $\mathrm{N}$ and other nutrients within the upper 20-cm layer compared with deeper layers. Variations in carbon and nitrogen, and in general, in organic matter levels with depth may also suggest rapid 


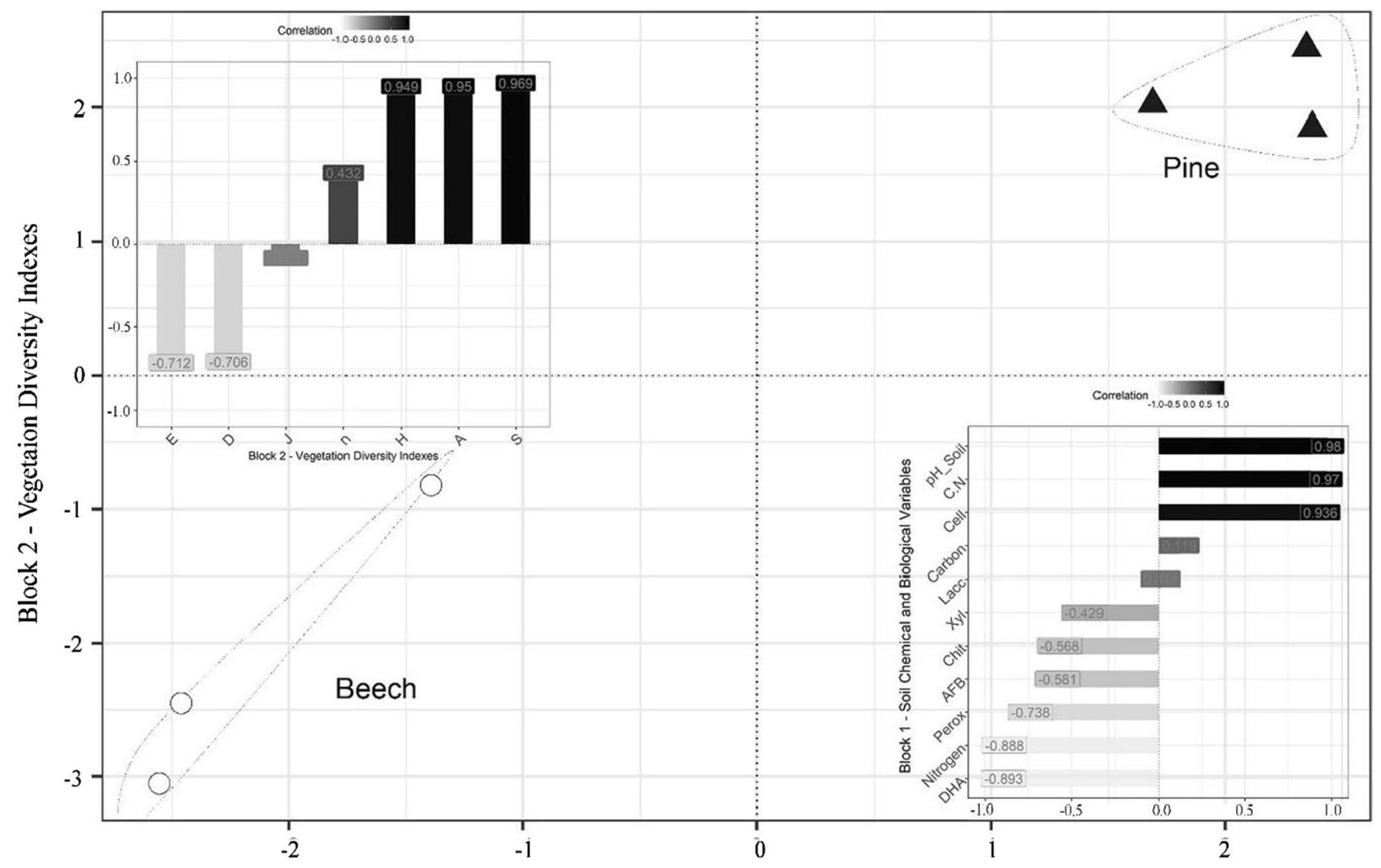

Block 1 - Soil Chemical and Biological Variables

Fig. 1 Scatterplot of the first axis of 2B-PLS between soil chemical and biological variables (Block 1) and vegetation diversity indexes (Block 2); inserts show the correlation within and between blocks

degradation and/or a slow vertical redistribution by mesofauna (De Marco et al. 2016; Fioretto et al. 2018; Innangi et al. 2018; Menta et al. 2018).

In general, decreases in organic matter with depth closely mirror changes in the total microbial and fungal biomass (Chen et al. 2005). Several studies have reported a decrease in soil enzyme activities with depth in forest soils (Aon and Colaneri 2001; Lindner et al. 2010; Fioretto et al. 2018; Zhang et al. 2019). Moreover, a strong correlation between the decrease in organic carbon and its readily utilizable forms with depth, and the vertical gradient of lignocellulosedegrading enzymes (Andersson et al. 2004; Wittmann et al. 2004) has been reported at an even finer scale (Šnajdr et al. 2008). Ushio et al. (2008) found that the soil microbial community showed some species specificity. We found that differences in the plant community are related to changes in the microbial biomass and its community structure. The most interesting question is whether these changes are related to differences in levels of organic $\mathrm{C}$ quantity and quality and to the physicochemical differences of the soil under the different species. Litter is the main source of soil organic matter influencing $\mathrm{pH}$ and $\mathrm{C}: \mathrm{N}$ ratios (Anderson and Hetherington
1999; Hilli et al. 2008; Kooch et al. 2016). In turn, pH and $\mathrm{C}: \mathrm{N}$ ratios play a major role in the composition of the microbial community (Bardgett et al. 2005; Hogberg et al. 2010). Beech plots showed consistently higher chitinase, dehydrogenase, and peroxidase enzyme activities than pine plots. Based on our results, soil enzymatic activity is connected with organic matter levels that in turn, is related to tree cover and undergrowth diversity. Higher organic matter provides sufficient substrate to support higher microbial biomass, hence higher enzyme production (Dilly et al. 1996; Innangi et al. 2017b). Several researchers have reported positive correlations between DHA and organic matter levels (Chodak et al. 2010; Moeskops et al. 2010; Romero et al. 2010; Zhao et al. 2010). Zhang et al. (2010) also indicated that DHA and $\mathrm{CaCO}_{3}$ were correlated with organic matter content, and, even more interestingly, that all three were correlated with each other in their spatial distribution, suggesting that abundant organic matter contributed to the formation of pedogenic calcium carbonate similar to the substrate present in ours stands. Salazar et al. (2011) hypothesized that activities of dehydrogenases in different forest ecosystems were involved in the carbon cycling, and they also noted a 


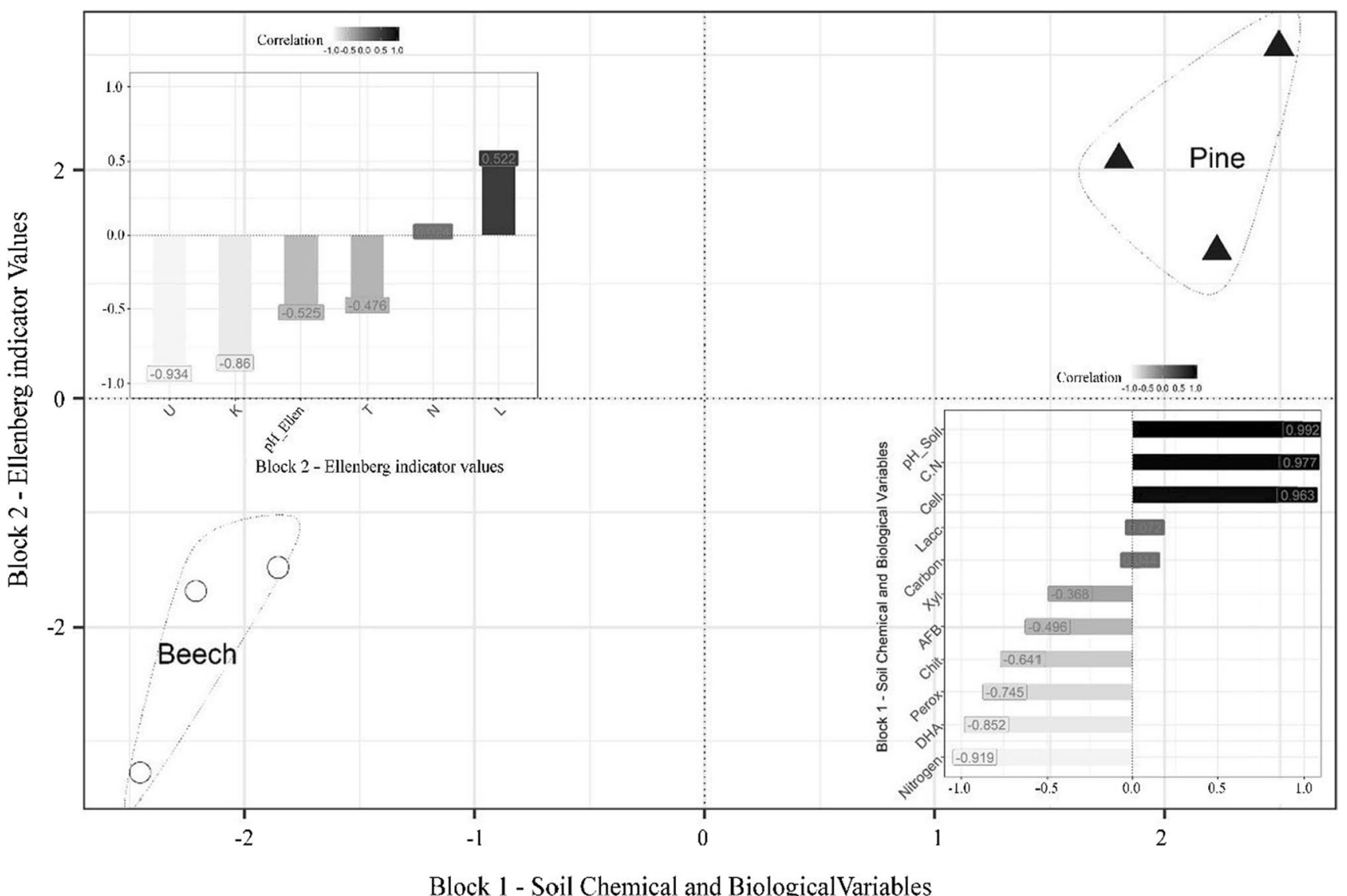

Fig. 2 Scatterplot of the first axis of 2B-PLS between soil chemical and biological variables (Block 1) and Ellenberg's indicator values (Block 2); inserts show the correlation within and between blocks

positive correlation. Chitinase has been reported to be an excellent proxy for fungal biomass (Innangi et al. 2020). An increase in total microbial biomass depends on the presence of fungi, but our data does not indicate whether the bacterial biomass also increased at the same time. Peroxidase, on the other hand, is an enzyme involved in the degradation of lignin (Palma et al. 2000). The higher activity of this enzyme under beech suggests enhanced activity of lignin- decomposing fungi compared to under pine cover, indicating a more specialized fungal community even though AFB and laccase were comparable between stand covers. In contrast, soil under pine showed a greater activity of cellulase and therefore a greater capacity for cellulose degradation (Fioretto et al. 2000). Thus, the different expressions of enzymatic activity shown here between the two types of soil, associated with different accumulations of organic $\mathrm{C}$ and different amounts of humic and fulvic acids (Curcio et al. 2017; Danise et al. 2018), showed different presence and composition of microbial communities.

Plant biodiversity provides a miscellaneous litter input in terms of quality and palatability for soil fauna and microbial communities, thus directly influencing the activity of decomposers and the composition of their community (Gartner and Cardon 2004). As a consequence, mixed litter input can affect the whole detrital food web (Salamon et al. 2008; Langenbruch et al. 2011; Błońska et al. 2016). It follows that plant diversity may be able to influence soil fertility (Nadeau and Sullivan 2015) and the carbon flow between its main pools in the soil (Vittori Antisari et al. 2011). Accordingly, the differences in soil chemical and biological variables are undoubtedly linked to the different tree cover that, in turn, was reflected in the biological and functional diversity of the vegetation. Admittedly, our research is limited by the lack of important information on forest structure such as tree heights and annual net primary productivity. However, this study was not intended to provide an in-depth survey of the vegetation, and our findings are in line with previous research on Mount Faito, both in terms of flora (Caputo et al. 1990) and vegetation (Cancellieri et al. 2017). The beech stand vegetation can be linked to the Anemono apenninae-Fagetum sylvaticae (Gentile 1970) Brullo 1983 syntaxon that represent the typical plant community of Italian thermophilous beech forests (Di Pietro et al. 2004). Diagnostic species of this type of vegetation 
are Anemone apennina, Euphorbia amygdaloides L., and Daphne laureola L.. The beech forests of Mount Faito are considered poorer in number of species compared to other beech forests in Campania, being almost at the lower elevation tolerance for Italian Apennine beech forests yet hosting some high quality species such as Italian alder (Alnus cordata) and glacial relicts such as Betula pendula Roth (Cancellieri et al. 2017). The vegetation under pine canopy, in contrast, was more diversified and not as straightforward to classify from a taxonomical point of view, considering the alteration as a result of plantation establishment. Some elements of the vegetation can be linked to the Asperulo taurinae-Alnetum cordatae Bonin 1977 in Bonin, Briane and Gamisans 1977 syntaxon, such as the presence of Castanea sativa and Acer opalus subsp. obtusatum in the canopy and Pteridium aquilinum (L.) Kuhn subsp. aquilinum in the undergrowth (Cancellieri et al. 2017). Nevertheless, the vegetation showed floristic elements of Fagetalia sylvaticae Pawl. in Pawlowski, Sokolowski and Wallisch 1928 such as Salvia glutinosa L., Vinca minor L., Euphorbia amygdaloides, and even young beech trees. Noticeably, no Italian alder was found under pine cover. The mixed and diversified vegetation of the pine stands can be linked to a situation of ecological disequilibrium linked to human interference (Pignatti 1994). The original vegetation of this area was altered by Count Girolamo Giusso (1843-1921) who acquired large sectors of the mountain and who, during the second half of the 19th and the first years of the twentieth century, had most of the original woods (Italian alders as well) replacing them with different species of conifers, including Pinus nigra subsp. nigra and Abies alba (Cavara 1914). Thus, Pinus nigra subsp. nigra is an alien species on Mount Faito and its impact on soil development has lasted for no more than 150 years. Noticeably, Pinus nigra subsp. nigra is a heliophilous species, one that tolerates high levels of sunlight to allow the development of less shade tolerant plants in the undergrowth such as blackberry, Rubus hirtus.

The altered vegetation under the pine cover, compared to the established beech forest, was reflected in soil chemical and biological properties, as shown by 2B-PLS. The higher dominance and evenness indexes in the beech stand (indicative of a more stable community) were reflected in higher values of DHA indicating greater microbial activity. When also considering the higher activity of peroxidase, a lignin decomposing enzyme produce by specialized fungi (Datta et al. 2017), it may be inferred that the microbial community in the beech stand reflects the stability and maturity of the vegetation as well. Such trends towards more specialized microbial communities and higher $\mathrm{C}$ stocks in the soil, along with the maturity of the vegetation, has been also shown during afforestation (Zhang et al. 2019) and within natural forests (Trap et al. 2013). The same trend also occurred when considering the plant community on an ecological and functional aspect, considering Ellenberg's indicator value. Accordingly, the pine plantation is differentiated from the beech stand by a less shade tolerant community, reflected in higher cellulase activity, less acidity, and broader C:N ratio. In contrast to peroxidase, cellulase activity can be linked to both fungi and bacteria, but it is generally considered an enzyme produced at earlier stages of development of the microbial succession and linked to the decomposition of organic matter (Frankland 1998; Maharning et al. 2009; Prescott and Grayston 2013; Kang et al. 2018).

In conclusion, our study shows that, despite a comparatively low sample size and within a small forest area that developed under general conditions, afforestation with Pinus nigra changed not only the vegetation but soil and microbial variables as well. These results highlight how long-lasting and significant are the effects of reforestation with allocthonous species within old-growth forests.

Authors' contributions Antonietta Fioretto designed the study conception and design. Material preparation, data collection and analysis were performed by Tiziana Danise, Michele Innangi and Elena Curcio. The first draft of the manuscript was written by Michele Innangi and Tiziana Danise and all authors commented on previous versions of the manuscript. All authors read and approved the final manuscript.

Funding Open access funding provided by Università degli Studi della Campania Luigi Vanvitelli within the CRUI-CARE Agreement.

\section{Declarations}

Conflicts of interest The authors declare that there is no conflict of interests.

Open Access This article is licensed under a Creative Commons Attribution 4.0 International License, which permits use, sharing, adaptation, distribution and reproduction in any medium or format, as long as you give appropriate credit to the original author(s) and the source, provide a link to the Creative Commons licence, and indicate if changes were made. The images or other third party material in this article are included in the article's Creative Commons licence, unless indicated otherwise in a credit line to the material. If material is not included in the article's Creative Commons licence and your intended use is not permitted by statutory regulation or exceeds the permitted use, you will need to obtain permission directly from the copyright holder. To view a copy of this licence, visit http://creativecommons.org/licenses/by/4.0/.

\section{References}

Anderson JM, Hetherington SL (1999) Temperature, nitrogen availability and mixture effects on the decomposition of heather [ $\mathrm{Cal}$ luna vulgaris (L.) Hull] and bracken [Pteridium aquilinum (L.) Kuhn] litters. Funct Ecol 13:116-124. https://doi.org/10.1046/j. 1365-2435.1999.00014.x 
Andersson M, Kjøller A, Struwe S (2004) Microbial enzyme activities in leaf litter, humus and mineral soil layers of European forests. Soil Biol Biochem 36:1527-1537. https://doi.org/10.1016/j.soilb io.2004.07.018

Aon MA, Colaneri AC (2001) II. Temporal and spatial evolution of enzymatic activities and physico-chemical properties in an agricultural soil. Appl Soil Ecol 18:255-270. https://doi.org/10.1016/ S0929-1393(01)00161-5

Bardgett RD, Bowman WD, Kaufmann R, Schmidt SK (2005) A temporal approach to linking aboveground and belowground ecology. Trends Ecol Evol 20:634-641. https://doi.org/10.1016/j.tree. 2005.08.005

Bartolucci F, Peruzzi L, Galasso G, Albano A, Alessandrini A, Ardenghi NMG, Astuti G, Bacchetta G, Ballelli S, Banfi E, Barberis G, Bernardo L, Bouvet D, Bovio M, Cecchi L, Di Pietro R, Domina G, Fascetti S, Fenu G, Festi F, Foggi B, Gallo L, Gottschlich G, Gubellini L, Iamonico D, Iberite M, JiménezMejías P, Lattanzi E, Marchetti D, Martinetto E, Masin RR, Medagli P, Passalacqua NG, Peccenini S, Pennesi R, Pierini B, Poldini L, Prosser F, Raimondo FM, Roma-Marzio F, Rosati L, Santangelo A, Scoppola A, Scortegagna S, Selvaggi A, Selvi F, Soldano A, Stinca A, Wagensommer RP, Wilhalm T, Conti F (2018) An updated checklist of the vascular flora native to Italy. Plant Biosyst An Int J Deal with all Asp Plant Biol 152:179-303. https://doi.org/10.1080/11263504.2017.1419996

Battipaglia G, Awada T, Der Aus AuR, Innangi M, Saurer M, Cherubini P (2020) Increasing atmospheric CO2 concentrations outweighs effects of stand density in determining growth and water use ef fi ciency in Pinus ponderosa of the semi-arid grasslands of Nebraska (U.S.A.). Glob Ecol Conserv. https:// doi.org/10.1016/j.gecco.2020.e01274

Berg B, Johansson M-B, Calvo de Anta R, Escudero A, Gärdenäs A, Laskowski R, Madeira M, Mälkönen E, McClaugherty C, Meentemeyer V, Virzo De Santo A (1995) The chemical composition of newly shed needle litter of Scots pine and some other pine species in a climatic transect. X Long-term decomposition in a Scots pine forest. Can J Bot 73:1423-1435. https://doi.org/10.1139/b95-155

Błońska E, Lasota J, Zwydak M, Piaszczyk W (2016) Stand mixing effect on enzyme activity and other soil properties. Soil Sci Annu 67:173-178. https://doi.org/10.1515/ssa-2016-0021

Bocci G (2015) TR8: an R package for easily retrieving plant species traits. Methods Ecol Evol 6:347-350

Braun-Blanquet J (1964) Pflanzensoziologie. Springer, Vienna

Campagnaro T, Brundu G, Sitzia T (2018) Five major invasive alien tree species in European Union forest habitat types of the alpine and continental biogeographical regions. J Nat Conserv 43:227-238. https://doi.org/10.1016/j.jnc.2017.07.007

Cancellieri L, Caneva G, Cutini M (2017) Phytosociology and ecology of the Mediterranean forests ecosystems in the Amalfi Coast (Monti Lattari, Italy). Rend Lincei 28:651-671. https:// doi.org/10.1007/s12210-017-0635-x

Caputo G, La Valva V, Nazzaro R, Ricciardi M (1990) La flora della Penisola Sorrentina (Campania). Delpinoa 31-32:3-97

Carpaneto G, Curtini M, Di Pietro R, Muscio G, Solari M (2006) Le faggete appeniniche: avanguardie e relitti di foresta continentale. In: Minelli A, Ruffo S, Stoch F (eds) Quaderni habitat. Ministero dell'Ambiente e della Tutela del Territorio, pp. 1-35

Carrascal LM, Galván I, Gordo O (2009) Partial least squares regression as an alternative to current regression methods used in ecology. Oikos 118:681-690. https://doi.org/10.1111/j.16000706.2008.16881.x

Cavara F (1914) La gita a Faito di Castellammare di Stabia. L'Alpe, ser II $1: 1-13$
Chen F, Kissel DE, West LT, Rickman D, Luvall JC, Adkins W (2005) Mapping surface soil organic carbon for crop fields with remote sensing. J Soil Water Conserv 60:51-57

Chodak M, Niklinska M, Niklińska M (2010) The effect of different tree species on the chemical and microbial properties of reclaimed mine soils. Biol Fertil Soils. https://doi.org/10.1007/ s00374-010-0462-z

Curcio E, Danise T, Innangi M, Alvarez Romero M, Coppola E, Fioretto A, Papa S (2017) Soil characterization and comparison of organic matter quality and quantity of two stands under different vegetation cover on Monte Faito Soil characterization and comparison of organic matter quality and quantity of two stands under different. Fresenius Environ Bullettin 26:8-18

Danise T, Fioretto A, Innangi M (2018) Spectrophotometric methods for lignin and cellulose in forest soils as predictors for humic substances. Eur J Soil Sci 69:1-12. https://doi.org/10.1111/ ejss. 12678

Danise T, Innangi M, Curcio E, Fioretto A, Guggenberger G (2020) Fast spectrophotometric method as alternative for $\mathrm{CuO}$ oxidation to assess lignin in soils with different tree cover. Forests 11:1-13. https://doi.org/10.3390/f11121262

Datta R, Kelkar A, Baraniya D, Molaei A, Moulick A, Swaroop Mena R, Formanek P (2017) Enzymatic degradation of lignin in soil: a review. Sustainability. https://doi.org/10.3390/su907 1163

De Marco A, Fioretto A, Giordano M, Innangi M, Menta C, Papa S, Virzo De Santo A (2016) C stocks in forest floor and mineral soil of two mediterranean beech forests. Forests 7:181. https:// doi.org/10.3390/f7080181

Di Gennaro A, Aronne G, De Mascellis R, Vingiani S, Sarnataro M, Abalsamo P, Cona F, Vitelli L, Arpia G (2002) I sistemi di terre della Campania. S.EL.CA, Firenze

Di Nardo C, Cinquegrana A, Papa S, Fuggi A, Fioretto A (2004) Laccase and peroxidase isoenzymes during leaf litter decomposition of Quercus ilex in a Mediterranean ecosystem. Soil Biol Biochem 36:1539-1544. https://doi.org/10.1016/j.soilbio.2004.07.013

Di Pietro R, Izco J, Blasi C (2004) Contribution to the nomenclatural knowledge of Fagus sylvatica woodlands of southern Italy. Plant Biosyst 138:27-36. https://doi.org/10.1080/112635004100016 84099

Dilly O, Munch JCJ, Dllly O, Munch JCJ (1996) Microbial biomass content, basal respiration and enzyme activities during the course of decomposition of leaf litter in a black alder (Alnus glutinosa (L.) Gaertn.). Soil Biol Biochem 28:1073-1081. https://doi.org/ 10.1016/0038-0717(96)00075-2

Fioretto A, Papa S, Curcio E, Sorrentino G, Fuggi A (2000) Enzyme dynamics on decomposing leaf litter of Cistus incanus and Myrtus communis in a Mediterranean ecosystem. Soil Biol Biochem 32:1847-1855. https://doi.org/10.1016/S0038-0717(00)00158-9

Fioretto A, Innangi M, De Marco A, Menta C, Papa S, Pellegrino A, Virzo De Santo A (2018) Discriminating between seasonal and chemical variation in extracellular enzyme activities within two italian beech forests by means of multilevel models. Forests. https://doi.org/10.3390/f9040219

Flynn DFB, Mirotchnick N, Jain M, Palmer MI, Naeem S (2011) Functional and phylogenetic diversity as predictors of biodiversity-Ecosystem-function relationships. Ecology 92:1573-1581. https://doi.org/10.1890/10-1245.1

Frankland JC (1998) Fungal succession-unravelling the unpredictable. Mycol Res 102:1-15. https://doi.org/10.1017/S095375629 7005364

Gartner TB, Cardon ZG (2004) Decomposition dynamics in mixedspecies leaf litter. Oikos 104:230-246. https://doi.org/10.1111/j. 0030-1299.2004.12738.x 
Guarino R, Domina G, Pignatti S (2012) Ellenberg's Indicator values for the Flora of Italy-first update: Pteridophyta, Gymnospermae and Monocotyledoneae. Flora Mediterr 22:197-209

Hedde M, Aubert M, Decaëns T, Bureau F (2008) Dynamics of soil carbon in a beechwood chronosequence forest. For Ecol Manage 255:193-202. https://doi.org/10.1016/j.foreco.2007.09.004

Hilli S, Stark S, Derome J (2008) Carbon quality and stocks in organic horizons in boreal forest soils. Ecosystems 11:270-282. https:// doi.org/10.1007/s10021-007-9121-0

Hogberg MN, Briones MJI, Keel SG, Metcalfe DB, Campbell C, Midwood AJ, Thornton B, Hurry V, Linder S, Näsholm T, Högberg P (2010) Quantification of effects of season and nitrogen supply on tree below-ground carbon transfer to ectomycorrhizal fungi and other soil organisms in a boreal pine forest. New Phytol 187:485-493. https://doi.org/10.1111/j.1469-8137.2010.03274.x

Innangi M, D’Alessandro F, Fioretto A, Di Febbraro M (2015a) Modeling distribution of Mediterranean beech forests and soil carbon stock under climate change scenarios. Clim Res 66:25-36. https://doi.org/10.3354/cr01323

Innangi M, Schenk MK, d'Alessandro F, Pinto S, Menta C, Papa S, Fioretto A (2015b) Field and microcosms decomposition dynamics of European beech leaf litter: influence of climate, plant material and soil with focus on N and Mn. Appl Soil Ecol 93:88-97. https://doi.org/10.1016/j.apsoil.2015.04.007

Innangi M, Danise T, d'Alessandro F, Curcio E, Fioretto A, D'Alessandro F, Curcio E, Fioretto A (2017a) Dynamics of Organic Matter in Leaf Litter and Topsoil within an Italian Alder (Alnus cordata (Loisel.) Desf.) Ecosystem. Forests 8:240. https://doi.org/10.3390/f8070240

Innangi M, Niro E, D’Ascoli R, Danise T, Proietti P, Nasini L, Regni L, Castaldi S, Fioretto A (2017b) Effects of olive pomace amendment on soil enzyme activities. Appl Soil Ecol 119:242249. https://doi.org/10.1016/j.apsoil.2017.06.015

Innangi M, Menta C, Pinto S, Danise T, D'Alessandro F, Fioretto A (2018) Integrating chemical, biological and soil fauna variables during beech leaf litter decay: a partial least squares approach for a comprehensive view of the decomposition process. Appl Soil Ecol 130:69-78. https://doi.org/10.1016/j.apsoil.2018.05. 023

Innangi M, Balestrieri R, Danise T, d'Alessandro F, Fioretto A (2019) From soil to bird community: a Partial Least Squares approach to investigate a natural wooded area surrounded by urban patchwork (Astroni crater, southern Italy). Ecol Modell 394:1-10. https:// doi.org/10.1016/j.ecolmodel.2019.01.002

Innangi M, Fioretto A, Lozano Fondón C, García-Montero LG, Marzaioli R, Pinto S, Rutigliano FA, Menta C (2020) Tuber aestivum is associated with changes in soil chemistry and reduced biological quality in a Quercus pubescens stand in Northern Italy. Pedobiologia J Soil Ecol 80:1-8. https://doi.org/10.1016/j. pedobi.2020.150648

Jandl R, Lindner M, Vesterdal L, Bauwens B, Baritz R, Hagedorn F, Johnson DW, Minkkinen K, Byrne KA (2007) How strongly can forest management influence soil carbon sequestration? Geoderma 137:253-268. https://doi.org/10.1016/j.geoderma.2006. 09.003

Jobbágy E, Jackson R (2000) The vertical distribution of soil organic carbon and its relation to climate and vegetation. Ecol Appl $10: 423-436$

Kang H, Gao H, Yu W, Yi Y, Wang Y, Ning M (2018) Changes in soil microbial community structure and function after afforestation depend on species and age: Case study in a subtropical alluvial island. Sci Total Environ 625:1423-1432. https://doi.org/10. 1016/j.scitotenv.2017.12.180

Kooch Y, Rostayee F, Hosseini SM (2016) Effects of tree species on topsoil properties and nitrogen cycling in natural forest and tree plantations of northern Iran. CATENA 144:65-73. https://doi. org/10.1016/j.catena.2016.05.002

Lal R (2005) Forest soils and carbon sequestration. For Ecol Manage 220:242-258. https://doi.org/10.1016/j.foreco.2005.08.015

Langenbruch C, Helfrich M, Flessa H (2011) Effects of beech (Fagus sylvatica), ash (Fraxinus excelsior) and lime (Tilia spec.) on soil chemical properties in a mixed deciduous forest. Plant Soil 352:389-403. https://doi.org/10.1007/s11104-011-1004-7

Leatham GF, Stahmann MA (1981) Studies on the laccase of Lentinus edodes: specificity, localization and association with the development of fruiting bodies. J Gen Microbiol 125:147-157

Lindner M, Maroschek M, Netherer S, Kremer A, Barbati A, GarciaGonzalo J, Seidl R, Delzon S, Corona P, Kolström M, Lexer MJ, Marchetti M (2010) Climate change impacts, adaptive capacity, and vulnerability of European forest ecosystems. For Ecol Manage 259:698-709. https://doi.org/10.1016/j.foreco.2009.09.023

Loreau M, Naeem S, Inchausti P, Bengtsson J, Grime JP, Hector A, Hooper DU, Huston MA, Raffaelli D, Schmid B, Tilman D, Wardle DA (2001) Biodiversity and ecosystem functioning: current knowledge and future challenges. Science 294:804-808. https:// doi.org/10.1126/science.1064088

Maharning AR, Mills AAS, Adl SM (2009) Soil community changes during secondary succession to naturalized grasslands. Appl Soil Ecol 41:137-147. https://doi.org/10.1016/j.apsoil.2008.11.003

Marzaioli R, D’Ascoli R, De Pascale RA, Rutigliano FA (2010) Soil quality in a Mediterranean area of Southern Italy as related to different land use types. Appl Soil Ecol 44:205-212. https://doi. org/10.1016/j.apsoil.2009.12.007

Masera OR, Garza-Caligaris JF, Kanninen M, Karjalainen T, Liski J, Nabuurs GJ, Pussinen A, de Jong BHJ, Mohren GMJ (2003) Modeling carbon sequestration in afforestation, agroforestry and forest management projects: the CO2FIX vol 2 approach. Ecol Modell 164:177-199. https://doi.org/10.1016/S0304-3800(02) 00419-2

McDaniel MD, Kaye JP, Kaye MW (2013) Increased temperature and precipitation had limited effects on soil extracellular enzyme activities in a post-harvest forest. Soil Biol Biochem 56:90-98. https://doi.org/10.1016/j.soilbio.2012.02.026

Menta C, Conti FD, Pinto S (2018) Microarthropods biodiversity in natural, seminatural and cultivated soils-QBS-ar approach. Appl Soil Ecol 123:740-743. https://doi.org/10.1016/j.apsoil. 2017.05.020

Midgley GF, Thuiller W (2005) Global environmental change and the uncertain fate of biodiversity. New Phyt 167:638-641. https:// doi.org/10.1111/j.1469-8137.2005.01522.x

Milad M, Schaich H, Bürgi M, Konold W (2011) Climate change and nature conservation in Central European forests: a review of consequences, concepts and challenges. For Ecol Manage 261:829843. https://doi.org/10.1016/j.foreco.2010.10.038

Moeskops B, Sukristiyonubowo BD, Sleutel S, Herawaty L, Husen E, Saraswati R, Setyorini D, De Neve S (2010) Soil microbial communities and activities under intensive organic and conventional vegetable farming in West Java, Indonesia. Appl Soil Ecol 45:112-120. https://doi.org/10.1016/j.apsoil.2010.03.005

Nadeau MB, Sullivan TP (2015) Relationships between plant biodiversity and soil fertility in a mature tropical forest, costa rica. Int J For Res 2015:1-13. https://doi.org/10.1155/2015/732946

Noce S, Collalti A, Santini M (2017) Likelihood of changes in forest species suitability, distribution, and diversity under future climate: the case of Southern Europe. Ecol Evol 7:9358-9375. https://doi.org/10.1002/ece3.3427

Oksanen J, Blanchet FG, Kindt R, Legendre P, Minchin PR, Ohara RB, Simpson GL, Solymos P, Stevens MHH, Wagner H (2013) Package 'vegan.' Commun Ecol Packag version 2:1-295

Olson FCW (1950) Quantitative Estimates of Filamentous Algae. Trans Am Microsc Soc 69:272-279 
Palma C, Martínez AT, Lema JM, Martínez MJ (2000) Different fungal manganese-oxidizing peroxidases: a comparison between Bjerkandera sp. and Phanerochaete chrysosporium. J Biotechnol 77:235-245

Pan Y, Birdsey RA, Fang J, Houghton RA, Kauppi PE, Kurz WA, Phillips OL, Shvidenko A, Lewis SL, Canadell JG, Ciais P, Jackson RB, Pacala SW, McGuire AD, Piao S, Rautiainen A, Sitch S, Hayes D, Canadell JG, Khatiwala S, Primeau F, Hall T, Quéré CL, Dixon RK, Kauppi PE, Kurz WA, Stinson G, Rampley GJ, Dymond CC, Neilson ET, Stinson G, Birdsey RA, Pregitzer K, Lucier A, Kauppi PE, Pan Y, Pan Y, Birdsey RA, Hom J, McCullough K, van Mantgem PJ, Breshears DD, Ciais P, Fang J, Chen A, Peng C, Zhao S, Ci L, Lewis SL, Phillips OL, Gloor M, Lewis SL, Lloyd J, Sitch S, Mitchard ETA, Laurance WF, Houghton RA, Friedlingstein P, Tarnocai C, Hooijer A, Page SE, Rieley JO, Banks CJ, McGuire AD, Goodale CL, Sarmiento JL, Schulze ED, Pacala SW, Phillips OL, Metsaranta JM, Kurz WA, Neilson ET, Stinson G, Zhao M, Running SW, Houghton RA, Richard A, Pekka E, Werner A, Oliver L, Simon L, Josep G, Robert B, Stephen W, David A (2011) A large and persistent carbon sink in the world's forests. Science 333:988-993. https:// doi.org/10.1126/science. 1201609

Panico SC, Memoli V, Esposito F, Maisto G, De Marco A (2018) Plant cover and management practices as drivers of soil quality. Appl Soil Ecol 129:34-42. https://doi.org/10.1016/j.apsoil.2018.05. 001

Panico SC, Esposito F, Memoli V, Vitale L, Polimeno F, Magliulo V, Maisto G, De Marco A (2020) Variations of agricultural soil quality during the growth stages of sorghum and sunflower. Appl Soil Ecol 152:103569. https://doi.org/10.1016/j.apsoil. 2020.103569

Papa S, Cembrola E, Pellegrino A, Fuggi A, Fioretto A (2014) Microbial enzyme activities, fungal biomass and quality of the litter and upper soil layer in a beech forest of south Italy. Eur J Soil Sci 65:274-285. https://doi.org/10.1111/ejss.12112

Parisi F, Pioli S, Lombardi F, Marchetti M, Tognetti R (2018) Linking deadwood traits with saproxylic invertebrates and fungi in European forests—a review. IForest 11:423-436. https://doi.org/ 10.3832/ifor2670-011

Pennesi R (2017) Dati e modelli della Flora Vascolare Italiana con i nuovi strumenti della biodiversity informatics. University of Trieste

Pignatti S (1994) Ecologia del Paesaggio. UTET, Bologna (Italy)

Pignatti S, Menegoni P, Pietrosanti S (2005) Biondicazione attraverso le piante vascolari. Valori di indicazione Second Ellenb per le specie della Flora d'Italia Braun-Blanquetia 39:97

Prescott CE, Grayston SJ (2013) Tree species influence on microbial communities in litter and soil: current knowledge and research needs. For Ecol Manage 309:19-27. https://doi.org/10.1016/j. foreco.2013.02.034

Pribyl DW (2010) A critical review of the conventional SOC to SOM conversion factor. Geoderma 156:75-83. https://doi.org/10. 1016/j.geoderma.2010.02.003

R Core Team (2019) R: A language and environment for statistical computing. R Foundation for Statistical Computing, Vienna, Austria. https://www.r-project.org/

Rohlf FJ, Corti M (2000) Use of two-block partial least-squares to study covariation in shape. Syst Biol 49:740-753. https://doi. org/10.1080/106351500750049806

Romero E, Fernández-Bayo J, Díaz JMC, Nogales R (2010) Enzyme activities and diuron persistence in soil amended with vermicompost derived from spent grape marc and treated with urea. Appl Soil Ecol 44:198-204. https://doi.org/10.1016/j.apsoil.2009.12. 006

Salamon JA, Scheu S, Schaefer M (2008) The Collembola community of pure and mixed stands of beech (Fagus sylvatica) and spruce
(Picea abies) of different age. Pedobiologia (Jena) 51:385-396. https://doi.org/10.1016/j.pedobi.2007.10.002

Salazar S, Sánchez LE, Alvarez J, Valverde A, Galindo P, Igual JM, Peix A, Santa-Regina I (2011) Correlation among soil enzyme activities under different forest system management practices. Ecol Eng 37:1123-1131. https://doi.org/10.1016/j.ecoleng.2011. 02.007

Sanchez G (2012) plsdepot: Partial Least Squares (PLS) Data Analysis Methods. R package version 0.1.17. https://cran.r-project.org/ package $=$ plsdepot

Sanderman J, Amundson R (2014) 10.7 - Biogeochemistry of decomposition and detrital processing. In: Heinrich HD, Turekian KK (eds) Treatise Geochem, 2nd edn. Elsevier Ltd., pp 217-272

Schimel DS, House JI, Hibbard KA, Bousquet P, Ciais P, Peylin $\mathrm{P}$, Braswell BH, Apps MJ, Baker D, Bondeau A, Canadell J, Churkina G, Cramer W, Denning AS, Field CB, Friedlingstein P, Goodale C, Heimann M, Houghton RA, Melillo JM, Moore B, Murdiyarso D, Noble I, Pacala SW, Prentice IC, Raupach MR, Rayner PJ, Scholes RJ, Steffen WL, Wirth C (2001) Recent patterns and mechanisms of carbon exchange by terrestrial ecosystems. Nature 414:169-172. https://doi.org/10.1038/35102500

Schinner F, von Mersi W (1990) Xylanase-, CM-Cellulase and invertase activity in soil: an improved method. Soil Biol Biochem 22:511-515. https://doi.org/10.1016/0038-0717(90)90187-5

Schulp CJE, Nabuurs GJ, Verburg PH (2008) Future carbon sequestration in Europe-Effects of land use change. Agric Ecosyst Environ 127:251-264. https://doi.org/10.1016/j.agee.2008.04.010

Sitzia T, Campagnaro T, Kowarik I, Trentanovi G (2016) Using forest management to control invasive alien species: helping implement the new European regulation on invasive alien species. Biol Invasions 18:1-7. https://doi.org/10.1007/s10530-015-0999-8

Sladonja B, Sušek M, Guillermic J (2015) Review on invasive tree of heaven (Ailanthus altissima (Mill.) swingle) conflicting values: assessment of its ecosystem services and potential biological threat. Environ Manage 56:1009-1034. https://doi.org/10.1007/ s00267-015-0546-5

Šnajdr J, Valášková V, Merhautová V, Herinková J, Cajthaml T, Baldrian P (2008) Spatial variability of enzyme activities and microbial biomass in the upper layers of Quercus petraea forest soil. Soil Biol Biochem 40:2068-2075. https://doi.org/10.1016/j. soilbio.2008.01.015

Söderström BE (1977) Vital staining of fungi in pure cultures and in soil with fluorescein diacetate. Soil Biol Biochem 9:59-63

Stinca A, Ravo M, Marzaioli R, Marchese G, Cordella A, Rutigliano FA, Esposito A (2020) Changes in multi-level biodiversity and soil features in a burned beech forest in the southern Italian coastal mountain. Forests 11:1-31. https://doi.org/10.3390/ f11090983

Sundman V, Sivelä S (1978) A comment on the membrane filter technique for estimation of length of fungal hyphae in soil. Soil Biol Biochem 10:399-401. https://doi.org/10.1016/0038-0717(78) 90065-2

Trap J, Hättenschwiler S, Gattin I, Aubert M (2013) Forest ageing: An unexpected driver of beech leaf litter quality variability in European forests with strong consequences on soil processes. For Ecol Manage 302:338-345. https://doi.org/10.1016/j.foreco. 2013.03.011

Ushio M, Wagai R, Balser TC, Kitayama K (2008) Variations in the soil microbial community composition of a tropical montane forest ecosystem: does tree species matter? Soil Biol Biochem 40:2699-2702. https://doi.org/10.1016/j.soilbio.2008.06.023

Verchot L, Borelli T (2005) Application of para-nitrophenol (pNP) enzyme assays in degraded tropical soils. Soil Biol Biochem 37:625-633. https://doi.org/10.1016/j.soilbio.2004.09.005

Vilà M, Espinar JL, Hejda M, Hulme PE, Jarošík V, Maron JL, Pergl J, Schaffner U, Sun Y, Pyšek P (2011) Ecological impacts of 
invasive alien plants: a meta-analysis of their effects on species, communities and ecosystems. Ecol Lett 14:702-708

Vittori Antisari L, Marinari S, Dell'Abate MT, Baffi C, Vianello G (2011) Plant cover and epipedon SOM stability as factors affecting brown soil profile development and microbial activity. Geoderma 161:212-224. https://doi.org/10.1016/j.geoderma.2010. 12.021

Von Mersi W, Schinner F (1991) An improved and accurate method for determining the dehydrogenase activity of soils with iodonitrotetrazolium chloride. Biol Fertil Soils 11:216-220. https://doi. org/10.1007/BF00335770

Wickham H (2016) ggplot2: elegant graphics for data analysis. Springer, NewYork

Wittmann C, Kähkönen MA, Ilvesniemi H, Kurola J, Salkinoja-Salonen MS (2004) Areal activities and stratification of hydrolytic enzymes involved in the biochemical cycles of carbon, nitrogen, sulphur and phosphorus in podsolized boreal forest soils. Soil Biol Biochem 36:425-433. https://doi.org/10.1016/j.soilb io.2003.10.019
Zhang N, He XD, Gao YB, Li YH, Wang HT, Ma D, Zhang R, Yang S (2010) Pedogenic carbonate and soil dehydrogenase activity in response to soil organic matter in Artemisia ordosica community. Pedosphere 20:229-235. https://doi.org/10.1016/S1002-0160(10) 60010-0

Zhang H, Xiong X, Wu J, Zhao J, Zhao M, Chu G, Hui D, Zhou G, Deng Q, Zhang D (2019) Changes in soil microbial biomass, community composition, and enzyme activities after half-century forest restoration in degraded tropical lands. Forests 10:1124. https://doi.org/10.3390/f10121124

Zhao B, Chen J, Zhang J, Qin S (2010) Soil microbial biomass and activity response to repeated drying-rewetting cycles along a soil fertility gradient modified by long-term fertilization management practices. Geoderma 160:218-224. https://doi.org/10. 1016/j.geoderma.2010.09.024

Publisher's Note Springer Nature remains neutral with regard to jurisdictional claims in published maps and institutional affiliations. 